\title{
Review
}

\section{Critiquing capitalism today. New ways to Read Marx}

\author{
Frederick Harry Pitts \\ Palgrave Macmillan, Basingstoke, 2018, x+279 pp., \\ ISBN: 978-3-319-62632-1
}

Contemporary Political Theory (2020) 19, S251-S254. https://doi.org/10.1057/s41296019-00351-x; published online 18 September 2019

In Critiquing Capitalism Today. New Ways to Read Marx, Pitts remains faithful to the English tradition inaugurated by Bacon. He has structured the text into two parts. The first is the pars construens while the second is the pars destruens. The text is also introduced by seven paragraphs not only about the topics covered by the research, but also about the mode of exposition. The first part takes into consideration, on the one hand, the Neue Marx-Lektüre/New Reading of Marx (NRM), a Marxist current in Germany that arouses opposition to MarxismLeninism and Social Democracy. The version of this 'reading' is rooted in the works of Bellofiore and Finelli (1998), Heinrich (2012), and Bonefeld (2010), and is based essentially on the concept of 'social validation.' On the other hand, postoperismo is introduced and, in part, the transition that Negri makes from operaismo to postoperismo. The latter embraces a Spinozist conception of reality, transforming the working class into a 'multitude,' while operaismo (Negri 1992), by contrast, relies upon the Copernican inversion accomplished by Tronti (1966). This is, to be sure, a position where 'power' is exclusively on the side of the working class.

Both parts revise Marxism. However, the first remains critical, in spite of the fact that it stresses the negative side of dialectics. The NRM can therefore be defined as a Marxism à-la-Frankfurt. To be sure, it is a theory of social validation that stems from the writings of the Frankfurt School. The second part absorbs directly the dialectic in Spinoza's monism. The result is that Negri and Hardt transfer to 'man' the characteristics that Spinoza placed in God: a subject-predicate inversion that goes against the tradition of the subject-object dialectic that Marx discovers in Feuerbach.

In the first part, Pitts explicitly aims to conceive value differently from traditional Marxism through the concept of 'social validation' borrowed by the NRM (p. 23). While the latter moves from work-time to value, Pitts starts from value to get to work and time. In other words, taking into consideration the

(c) 2019 Springer Nature Limited. 1470-8914 Contemporary Political Theory Vol. 19, S4, S251-S254 
'socially necessary labor-time' (SNLT) of the first book of Capital, the NRM focuses on the social abstraction of concrete works mediated by the exchange of goods (p. 24). In this sense, value is not a certain amount of labor-time spent in production through concrete work, but is rather the SNLT through abstract labor (p. 27). The idea of this version of 'value theory' comes to him from the first book of Capital, whereas it is from the third book of Capital that the NRM reveals another typical tenet of Marxism: the critique of political economy as social criticism, and not merely as offering a distinct and alternative political economy to the bourgeois economy.

The author traces the transformation between traditional Marxism and NRM via value-form theory. This approach is called circulationist because it considers private work to be only potentially abstract and social. Here private and concrete work is turned social and abstract only through the exchange of labor products for money. In short, if in traditional Marxism prices are value-based on socially necessary average working time, in value-form theory prices are a function of the 'social validation' (of labor).

According to Pitts, Bellofiore is probably the main representative of the circulationist (or monetary) theory of value theory exhibited by the NRM. This position states that value does not reside exclusively in production, but rather has its roots in 'social validation' (of expended labor), which occurs in the circulation process. In other words, if the product of labor is not exchanged for money, the value is non-existent.

The concept of 'social validation' is the main concept of the whole book. It is also the substratum of the criticism of postoperaismo (Hard and Negri 2001). The introduction by Heinrich (2012) to the three volumes of Capital is Pitts's starting point in considering the concept of 'social validation.' The exchange validates concrete work as abstract labor. However, this reduction posits concrete work as 'valueless' in general (p. 39), whereas this is only true for particular forms of concrete work. Thus, Pitts comes to the conclusion that value-form has practical implications and that value determination belongs either to the sphere of production or the sphere of circulation. This value theory is the so-called 'monetary theory of value' expounded by the NRM.

The pars destruens is mainly addressed to Negri, not only to the legacy of the Copernican inversion of Tronti, but also to its 'Spinozian turn.' However, while in the first case the dialectic is saved, in the second it disappears. That happened after the 1980s when Negri embraced immanence, replacing the class struggle as the 'engine of history' with monism. This approach is clearly in tension with the assumptions of the NRM: the latter focuses on mediation, while Negri's Marxian Spinozism is completely immersed in immediacy.

The production relations, mediated by money, are not seen as constrictive by operaismo, but rather as an expression of the expansion of needs by the working class. This implies another essential distinction: the one between work and leisure. Work becomes directly synonymous with life. For traditional Marxism, the 
capitalist mode of production converts life itself into a commodity. By contrast, Marxian Spinozism mystifies the production of commodities by assuming the present realization of communism within the capitalist mode of production. In fact, eliminating the distinction between work and leisure implies that the transition from the private ownership of the means of production to a classless society, a transition called 'communism,' has already borne its fruits, that is, it has already consolidated a world free of private property, of commodities, and of the relations of production that determine it.

In short, Negri made the mistake of many Marxist or bourgeois commentators: they presuppose the full realization of the capitalist mode of production. But, as Pitts remembers, Negri's Marxian Spinozism is not a typical feature of autonomism or of the transition from operaismo to postoperaismo, but rather the expression of an 'affirmative theory' of the capitalist mode of production. The neo-Spinozism of Negri, states Pitts, is a Schopenhauerian Weltanschauung of seeing history as 'will' and 'subjectivity' (pp. 162-163).

The opposition between NRM and postoperaismo turns, therefore, into one between content and form, between quantity and quality. The NRM is fixed on the key concept of 'social validation' and keeps the dialectic apparently alive, concentrating on the negative moment. On the other hand, the transition from operaismo to postoperismo operated by Negri elides the dialectic and eliminates transcendence and abstraction as essential conditions for the social validation of thousands of distinct concrete works.

In conclusion, the position that emerges in the text is what Lukács calls 'Grand Hotel Abyss' (1988), typical of the Frankfurt School. The first problem is the focus on negation. Pitts's negation is no longer a mediation, but something immediate. He has performed Jacobi's salto mortale. The clock of history goes back to the justificationist period of romanticism. An immediate mediation is only a result, but it is posited as a point of departure. If the immediate mediation were taken as a point of departure, there would be an adaequatio rei et intellectus. In short, Pitts's social validation would be closer to Aquinas's medieval-style idealism or Hegel's absolute idealism, rather than Marxism.

Indeed, the problem of 'extension' arises. On the one hand, classical Marxism had focused on the real basis of society, i.e., production, on the basis of which one could articulate a critique of political economy - or 'the anatomy of society,' in Marx's words. But anatomy is ruled by necessity, and has to be known. On the other hand, Pitts's views, shifting attention to an ion society in general, dispels the possibility that revolutionary forces channel their resources towards a fundamental point: the intrinsic logic of the capitalist mode of production. The most profound contradictions of the capitalist mode of production are hidden in the theory of 'social validation.'

The implication of such a shift is a typical trait of postmodernism: the absence of fixed points. Finally, the theory of value introduced in this book abandons the

(C) 2019 Springer Nature Limited. 1470-8914 Contemporary Political Theory Vol. 19, S4, S251-S254 S253 
dialectic, and seems to justify the capitalist mode of production via a sort of Millian utilitarianism, where the concept of 'happiness' is replaced by 'social validation.' Eventually, the crises of overproduction - necessary within the capitalist mode of production - would be deduced from 'social validation,' i.e., from an effect, and not from intrinsic causal laws.

\section{References}

Bellofiore, R. and Finelli, R. (1998) Capital, Labour and Time: The Marxian Monetary Theory of Value as a Theory of Exploitation. In: R. Bellofiore (ed.) Marxian Economics: A Reappraisal: Essay on Volume 1 of Capital: Method, Value and Money (pp. 48-78). London: Macmillan.

Bonefeld, W. (2010) Abstract Labour: Against its Nature and on its Time. Capital and Class 34(2): 257-276.

Hardt, M. and Negri, A. (2001) Empire. Cambridge, MA: Harvard University Press.

Heinrich, M. (2012) An Introduction to the Three Volumes of Karl Marx's Capital. New York: Monthly Review Press.

Lukács, G. (1988) The Theory of the Novel. London: Merlin Press.

Negri, A. (1992) Marx beyond Marx: Lessons on the Grundrisse. London: Pluto.

Tronti, M. (1966) Operai e Capitale. Torino: Giulio Einaudi Editore.

Publisher's Note Springer Nature remains neutral with regard to jurisdictional claims in published maps and institutional affiliations.

Dario Cositore

University Pompeu Fabra, 08002 Barcelona, Spain dario.cositore01@estudiant.upf.edu 